\title{
PEMANFAATAN SERAT BAMBU PADA PEMBUATAN PANEL SERAT SEMEN SEBAGAI ALTERNATIF DINDING PENYEKAT RUANGAN
}

\author{
Wahyuning Handayani, Gina Bachtiar, dan Nira Nasution
}

\begin{abstract}
The Advantage Fiber Of A Bamboo to Make Fiber Cement Panel As Alternative The Wall Of Room. Skripsi, Jakarta : Civil Enginnering Direction, Engineering Faculty, United State Of Jakarta, Agustus 2009.

This research purpose for know aflexibelity fiber cement panel as advantage a fiber of a bamboo. As alternative wall of a room with mixed I $\mathrm{kg}$ of Portland cement composite (PCC) : 0,5 kg water : $2 \% \mathrm{CaCl}_{2}$ (calcium chloride). Do what the material is 3\%, 5\% and $7 \%$ fiber of bamboo. Test of a flexibility with Flexibility Machine (UTM INSTRON). Research of method in use is the experiment methods to follow with SNI 15-0233-1989 (About Quality and Methods Flexibility Test Of Cement Fiber).

To do carry about this research in workshop of the wood. Forest Faculty Institute Agricultural Bogor (IPB) and laboratorium of the non metal research material center and Industrial Departement Of DKI on Letjen Suprapto rood Cempaka Putih central Jakarta. For water resistant test and weight cement fiber panel. In the laboratorium of the wood Forest Faculty (IPB) use 3 Laboratorium is Bio Composite laboratorium for making it solid wood laboratorium for measure and technics wood laboratorium for flexibility test, time for doing this research in April 2009 - June 2009.

Product of research is what a different flexibility in mixing different fiber. Score of biggest the flexibility from the carry. Is used mixed 5\% but score of minimum the flexibility is not more than from the score of flexibility grade minimum cement fiber standard.
\end{abstract}

Keyword: fiber of a bamboo

\section{PENDAHULUAN}

Sebagaimana diketahui, kebutuhan dinding penyekat selalu meningkat dari tahun ke tahun sesuai dengan pembangunan gedung-gedung bertingkat atau rumah. 
Dengan keadaan seperti ini perlu dicari bahan alternatif untuk pengganti batu bata, batako dan kayu sebagai dinding penyekat yaitu salah satunya dengan panel serat bambu.

Dengan demikian diperlukan upaya untuk mengembangkan pola pemanfaatan yang optimal. Salah satu usaha yang dapat dilakukan dengan memanfaatkan serat bambu sebagai bahan pengisi dalan campuran dinding panel maka peneliti mencoba menggunakan serat bambu sebagai bahan pengisi didalam campuran dinding panel dengan presentase 3\%, $5 \%$, dan $7 \%$ dari berat semen sebagai alternatif dinding penyekat.

\section{Pembatasan Masalah}

Penelitian ini akan memberikan batasan yaitu hanya pada penggunaan Serat Bambu 3\%, $5 \%$, dan $7 \%$ terhadap berat semen sebagai bahan pengisi panel serat semen terhadap kuat lentur panel serat semen.

\section{Perumusan Masalah}

Dari pembatasan masalah diatas dapat dirumuskan masalahnya sebagai berikut :

1. Apakah ada perbedaan antara kuat lentur panel serat semen yang menggunakan bahan pengisi serat bambu sebesar $3 \%, 5 \%$, dan $7 \%$ terhadap berat semen?

2. Apakah nilai kuat lentur panel serat semen optimum yang menggunakan bahan pengisi serat bambu lebih tinggi dari pada kuat lentur standar?

\section{Kegunaan Penelitian}

Penelitian ini diharapkan dapat berguna sebagai berikut :

1. Salah satu sumber informasi pengetahuan khususnya dalam ilmu bahan bangunan bagi dunia pendidikan pada umummnya dan mahasiswa jurusan Teknik Sipil Universitas Negeri Jakarta pada khususnya.

2. Untuk mempelajari kemungkinan penggunaan serat bambu sebagai bahan pengisi pada campuran panel serat semen.

3. Mengetahui nilai kuat lentur panel serat semen dengan bahan pengisi serat bambu.

4. Upaya memberikan nilai tambah terhadap bambu sebagai bahan bangunan

\section{Kerangka Teoritis}




\section{Lembaran Serat Semen}

Lembaran serat semen (non asbes) adalah suatu campuran serat tumbuh-tumbuhan dan semen Portland atau semen sejenisnya ditambah air, tanpa atau dengan bahan tambahan lainnya, dengan bobot isi lebih dari 1,2 gram/ $\mathrm{cm}^{3}$ dan dipergunakan untuk bangunan (SNI 15-0233-1989. h,1.). Lembaran serat semen banyak digunakan di Indonesia khususnya untuk dinding penyekat ruangan (panel), plafond, atap dan lantai.

Syarat ukuran dan sifat-sifat physis lembaran serat semen berdasarkan SNI 15-02331989 adalah sebagai berikut : a) Tebal minimum 4 mm, dengan penyimpangan maksimum 10\%. b) Penyimpangan ukuran panjang dan lebar maksimal 1\%. c) Penyerapan air maksimum 35\%. d) Kerapatan air harus baik (tidak terjadi terjadi tetesan). e) Kuat lentur minimum rata-rata $100 \mathrm{~kg} / \mathrm{cm}^{2}$.

\section{a. Bahan Baku Lembaran Serat Semen}

1) Semen Portland Komposit

Tabel 1. Komposisi Semen Portland Komposit

\begin{tabular}{|l|l|}
\hline Komposisi Kimia & Kadar (\%) \\
\hline Kapur $(\mathrm{CaO})$ & $58-65$ \\
Silika $\left(\mathrm{SiO}_{2}\right)$ & $20-26$ \\
Alumunium Oksida $\left(\mathrm{Al}_{2} \mathrm{O}_{3}\right)$ & $5-9$ \\
Oksida $\left(\mathrm{Fe}_{2} \mathrm{O}_{3}\right)$ & $1-5$ \\
Magnesia (MgO) & $1-4$ \\
Trioksid Belerang $\left(\mathrm{SO}_{3}\right)$, max & 4 \\
Belerang (S) & $0,3-2$ \\
\hline
\end{tabular}

Sumber : SNI 15-7064-2004, Semen Komposit (Jakarta : Badan Standardidasi Nasional, 2004), h.4.

2) Air

Sebaiknya digunakan air bersih yang dapat diminum. Fungsi air dalam pembuatan dinding panel adalah untuk reaksi pengerasan semen, disamping itu juga sebagai pengatur kekentalan adukan. 


\section{3) Serat Bambu}

Serat bambu merupakan helaian benang-benang atau serat-serat yang berwarna putih kekuningan, berdiameter kurang dari $0.05 \mathrm{~mm}$ dan tidak mudah putus (Miko Erniarti, Ismail Hoesain. 2007,h.8.). Serat bambu pada dasarnya sangat menentukan kekuatan bambu. Serat-serat tersebut terdistribusi tidak merata disekitar penampang. Secara umum $40 \%$ hingga $70 \%$ serat terkonsentrasi di bagian luar dan $15 \%$ hingga $30 \%$ dibagian dalam batang. Serat bambu terdiri dari dua bagian yaitu sel-sel serat dan sel-sel non serat atau debu pati (Suparjo, Shofia Rawiana,. 2002 ,h.14).

Serat bambu diambil dari bagian kulit dengan ketebalan 30\% dari ketebalan total karena relatif padat sifat higroskopisnya rendah dan tidak memerlukan lapisan kedap air, kembang susut kecil, dengan kuat tarik $2052 \mathrm{~kg} / \mathrm{cm}^{2}$, tiga kali kuat tarik bagian dalam.

Bambu memiliki 50 - 55 \% lebih banyak selulosa daripada kayu. Serat bambu merupakan bahan organik. Oleh karena itu apabila dicampur dengan bahan organik lain seperti semen, maka daya rekat antara keduanya menjadi kurang baik, karena dari itu bambu sendiri sebagai bahan organik masih terdapat zat ekstraktif yang dapat menghambat pengikatan antara serat bambu dengan semen.

Untuk menghilangkan zat ekstraktif dari serat bambu dilakukan dengan cara merendam terlebih dahulu dengan air dingin selama 24 jam atau pemberian campuran berupa larutan kapur terhadap adukan dinding panel.

Cara menghitung test penyerapan air dapat dengan rumus : (SNI 15-0233-1989. h,1.)

$$
\text { Berat basah - Berat kering } \times 100 \%
$$

Berat kering

\section{b. Pembuatan Serat Bambu}

Langkah-langkah pembuatan serat bambu adalah sebagai berikut : a) Bambu tali dipotong sepanjang kira-kira $\pm 25 \mathrm{~cm}$ (Gambar 1), b) Kemudian potongan-potongan tersebut dibelah menjadi 8 bagian (Gambar 2), c) Kulit luar dan kulit dalam dibuang, d) Bambu tersebut dibelah lagi dengan ketebalan kira-kira 2 mm (Gambar 3), e) Belahan tersebut dibelah lagi kecil-kecil dengan ukuran $25 \times 0.2 \times 0.2 \mathrm{~cm}$ (Gambar 4), f) 
Selanjutnya salah satu ujung potongan tersebut diruncingkan agar dapat dimasukkan kedalam pelat penyerat dari lubang terbesar (garis tengah $2 \mathrm{~mm}$ ), lubang tengah (diameter $1.5 \mathrm{~mm}$ ) dan lubang kecil (garis tengah $1 \mathrm{~mm}$ ), secara bergantian dengan cara ditarik dengan menggunakan tang (Gambar 5), g) Serat dengan garis tengah $1 \mathrm{~mm}$ sepanjang $25 \mathrm{~cm}$ hasil penyeratan dipotong dengan panjang $1,2 \mathrm{~cm}$ dan kemudian di rendam selama 24 jam untuk menghilangkan zat ekstraktif dalam serat bambu. Setelah direndam selama 24 jam maka serat bambu itu di keringkan dengan cara di anginanginkan.

\section{c. Kuat Lentur}

Kuat lentur pada bambu adalah kekuatan untuk menahan gaya-gaya yang berusaha melengkungkan batang bambu atau menahan muatan mati atau hidup (Heinz. 2004, h.7). Karena bambu merupakan bahan yang elastis, maka lendutan yang terjadi sesuai dengan kekuatan bahan menjadi agak tinggi (rata-rata 1/20).

Kuat lentur dihitung menggunakan persamaan berikut :

$$
\text { Kuat lentur : } \frac{3 \mathrm{Pl}}{2 \mathrm{bh}^{2}} \mathrm{~kg} / \mathrm{cm}^{2}
$$

Keterangan :

P : beban patah $(\mathrm{kg})$

I : jarak tumpuan $(\mathrm{cm})$

b : lebar benda uji (cm)

h : tebal rata-rata bidang pecah $(\mathrm{cm})$

Dalam penelitian ini yang dimaksud dengan kuat lentur panel serat bambu adalah nilai kuat lentur optimum panel serat bambu yang didapat dari hasil pengujian benda uji berdasarkan mesin kuat lentur yang ditunjukkan ketika diberikan beban maksimum sehingga menghasilkan nilai rata-rata kuat lentur. Pengujian kuat lentur diperlukan karena dinding menerima beban horizontal seperti beban angin, serta beban vertikal seperti beban sendiri.

\section{Kerangka Berpikir}


Serat bambu memiliki sifat yang baik dalam kelenturan sehingga dapat digunakan untuk meningkatkan kuat lentur panel. Apabila serat semen mengalami beban pada saat pemakaian maka panel serat semen tidak akan terlalu pegas dan akan mempunyai kelenturan.

Adanya interaksi antar unsur-unsur pembentuk yaitu semen Portland Komposit, serat bambu dan air diharapkan akan menambah kekuatan lentur.

\section{Perumusan Hipotesis}

Berdasarkan kerangka berpikir di atas dapat dirumuskan hipotesis penelitian yaitu :

1. Terdapat perbedaan yang signifikan pada penambahan serat bambu terdapat nilai kuat lentur panel dengan persentase penambahan $3 \%, 5 \%$ dan $7 \%$ terhadap berat semen.

2. Nilai kuat lentur yang optimum panel serat semen yang menggunakan serat bambu lebih tinggi dari pada kuat lentur standar.

\section{METODOLOGI PENELITIAN}

\section{Tujuan Penelitian}

Tujuan penelitian ini adalah untuk mengetahui dan membuktikan apakah serat bambu dengan menggunakan bambu tali (Gigantochloa apus) dapat digunakan sebagai bahan pengisi dalam pembuatan lembaran serat semen dan mutu yang dihasilkan memenuhi standar SNI 15-0233-1989 (tentang mutu dan cara uji lembaran serat semen).

\section{Tempat dan Waktu Penelitian}

Penelitian dilakukan di 2 tempat yaitu laboratorium Keteknikan Kayu Fakultas Kehutanan Institut Pertanian Bogor (IPB) yang terletak di jalan Raya Darmaga Bogor, dengan menggunakan tiga jenis lab yaitu Lab Bio Komposit untuk pembuatan, Lab Kayu Solid untuk pengukuran serta Lab Keteknikan Kayu untuk pengujian kuat lentur dan Laboratorium bahan non logam Balai Penelitian Bahan dan Barang Teknis Dinas Perindustrian DKI yang beralamat dijalan Letjen Suprapto Cempaka Putih Jakarta Pusat untuk pengujian kerapatan air dan bobot isi panel serat semen. Waktu pelaksanaan penelitian antara bulan April 2009 sampai Juni 2009.

\section{Variabel Penelitian}

Pada penelitian ini terdapat dua variabel yaitu : 
1. Variabel terikat yaitu nilai mutu lembaran serat semen (SNI 15-0233-1989)

2. Variabel bebas yaitu panel serat semen yang menggunakan serat bambu dengan presentase $3 \%, 5 \%$ dan $7 \%$.

\section{Metode Penelitian}

Metode penelitian yang akan dilakukan dalam penelitian ini adalah metode eksperimen yang pelaksanaannya dilakukan di laboratorium, dengan penelitian ini hanya melibatkan dua kelompok benda uji yaitu kelompok benda uji lembaran serat semen dengan bahan baku serat bambu dan sebagai pembanding adalah lembaran serat semen yang telah memenuhi standar mutu (SNI 15-0233-1989 "Mutu dan cara uji lembaran serat semen.

\section{HASIL PENELITIAN}

\section{Hasil Pengujian Penyerapan Air Rata-Rata Panel Serat Bambu}

Tabel 2. Penyerapan Air Rata-rata Panel Serat Semen

\begin{tabular}{|c|c|c|c|c|}
\hline \multirow[t]{2}{*}{ No. } & \multirow[t]{2}{*}{ Perlakuan } & \multicolumn{2}{|c|}{ Berat (gram) } & \multirow[t]{2}{*}{ Penyerapan Air (\%) } \\
\hline & & Jenuh & Kering & \\
\hline 1 & $A$ & 65,70 & 88,57 & 35,39 \\
\hline 2 & $B$ & 63,23 & 87,40 & 38,31 \\
\hline 3 & C & 63,70 & 90,20 & 42,12 \\
\hline
\end{tabular}

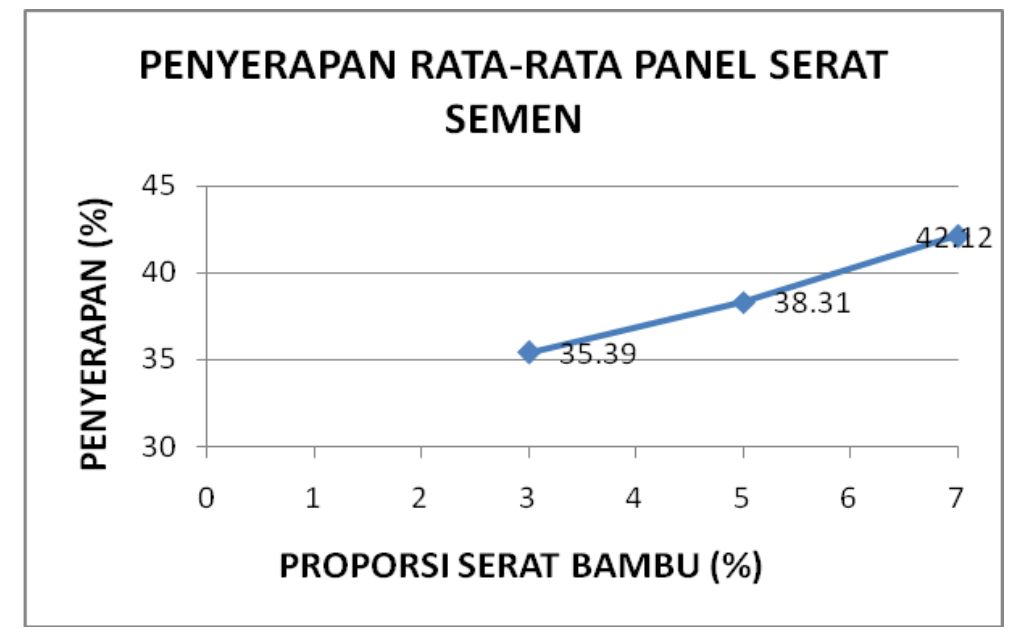


Gambar 1. Hubungan Penggunaan Campuran Serat Bambu dengan Penyerapan Air Panel Serat Semen.

\section{Hasil Pengujian Bobot Isi Rata-Rata Panel Serat Bambu}

Tabel 3. Bobot Isi Rata-rata Panel Serat Semen

\begin{tabular}{|c|c|c|c|c|c|}
\hline No. & Perlakuan & \multicolumn{3}{|c|}{ Berat (gr) } & $\begin{array}{c}\text { Bobot Isi } \\
\left(\mathrm{kg} / \mathrm{cm}^{2}\right)\end{array}$ \\
\cline { 3 - 5 } & & Jenuh & Kering & Dlm. Air & 1,12 \\
\hline 1 & A & 65,70 & 88,57 & 30,07 & 1,17 \\
\hline 2 & B & 63,23 & 87,40 & 33,27 & 1,22 \\
\hline
\end{tabular}

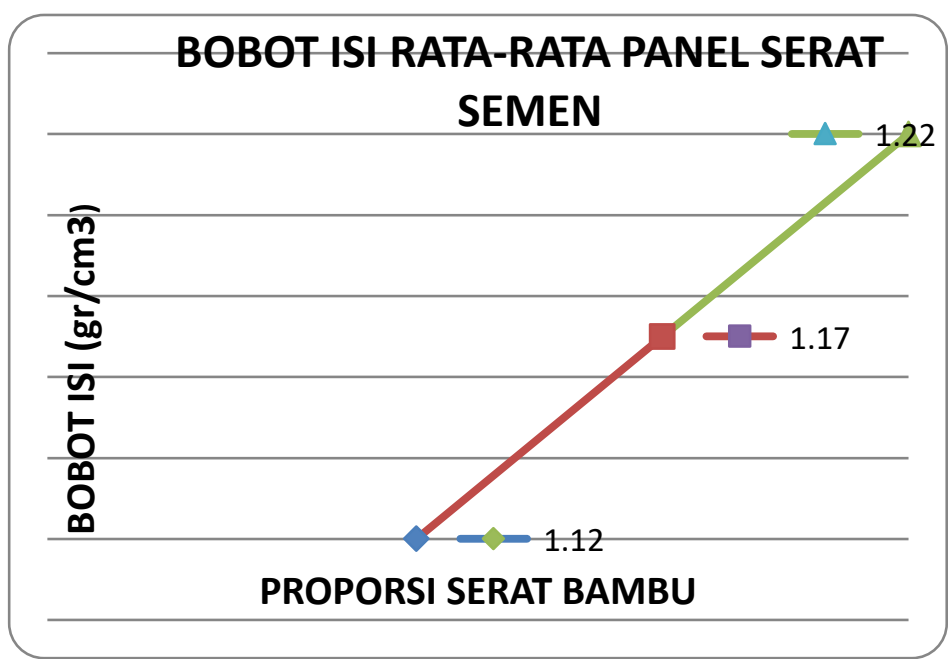

Gambar 2. Hubungan Penggunaan Campuran Serat Bambu dengan Bobot Isi Panel Serat Semen

\section{Hasil Pengujian Kuat Lentur Rata-Rata Panel Serat Bambu}

Pengujian kuat lentur panel serat semen dilakukan dengan pembebanan terpusat langsung di atas 2 pisau penumpu yang jaraknya $20 \mathrm{~cm}$ dengan kecepatan kurang lebih 1 $\mathrm{kg}$ per detik, sampai benda uji patah. Adapun ukuran benda uji adalah $25 \times 10 \times 1,2 \mathrm{~cm}$ dengan jumlah benda uji 45, berumur 28 hari. Sampel yang digunakan dalam penelitian ini untuk Tipe A (3\%) sebanyak 13 sampel, Tipe B (5\%) sebanyak 12 sampel dan Tipe $C(7 \%)$ sebanyak 14 sampel. Sebelum dilakukan pengujian terlebih dahulu benda uji di ukur tebalnya. 
Tabel 4. Kuat Lentur Rata-rata Panel Serat Semen

\begin{tabular}{|c|c|c|c|}
\hline \multirow[t]{2}{*}{ No } & \multicolumn{3}{|c|}{ Perlakuan $\left(\mathrm{kg} / \mathrm{cm}^{2}\right)$} \\
\hline & $\begin{array}{c}\text { A } \\
\text { (Campuran Serat 3\%) }\end{array}$ & $\begin{array}{c}\text { B } \\
\text { (Campuran Serat 5\%) }\end{array}$ & $\begin{array}{c}\text { C } \\
\text { (Campuran Serat } 7 \%)\end{array}$ \\
\hline 1 & 16,788 & 28,376 & 26,750 \\
\hline 2 & 12,670 & 31,349 & 23,123 \\
\hline 3 & 16,266 & 31,879 & 22,015 \\
\hline 4 & 12,253 & 29,327 & 23,817 \\
\hline 5 & 17,408 & 23,158 & 22,792 \\
\hline 6 & 15,189 & 21,293 & 22,887 \\
\hline 7 & 10,167 & 25,121 & 18,492 \\
\hline 8 & 12,949 & 13,022 & 14,239 \\
\hline 9 & 15,722 & 25,933 & 28,194 \\
\hline 10 & 12,725 & 16,785 & 25,902 \\
\hline 11 & 12,494 & 14,746 & 13,699 \\
\hline 12 & 12,325 & 15,705 & 14,165 \\
\hline 13 & 18,793 & & 17,978 \\
\hline 14 & & & 21,949 \\
\hline$\sum x$ & 185,749 & 276,694 & 296,002 \\
\hline $\mathrm{N}$ & 13 & 12 & 14 \\
\hline $\mathrm{X}$ & 14,288 & 23,058 & 21,143 \\
\hline
\end{tabular}

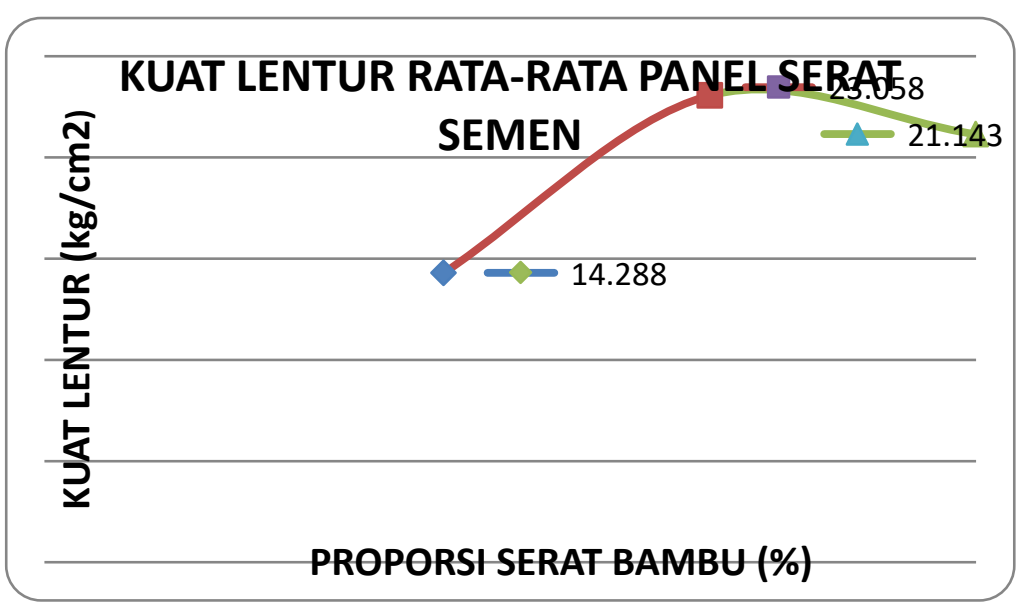

Grafik 3. Hubungan Penggunaan Campuran Serat Bambu dengan Kuat Lentur Panel Serat Semen 


\section{KESIMPULAN}

Berdasarkan hasil penelitian dan pengujian yang telah dilakukan menurut ruang lingkup prosedur pada SNI 15-0233-1989 mengenai "Mutu dan cara uji lembaran serat semen" meliputi syarat mutu, cara uji dan syarat lulus uji serat semen.

Hasil yang disimpulkan dari hipotesis yang telah di uji adalah sebagai berikut:

1. Panel serat semen yang menggunakan bahan campuran serat bambu yang berbeda antara 3\%,5\% dan 7\% secara signifikan terdapat perbedaan dalam hal nilai kuat lentur rata-ratanya.

2. Nilai kuat lentur rata-rata yang optimum ternyata di bawah standar $\left(100 \mathrm{~kg} / \mathrm{cm}^{2}\right)$, hal ini menunjukkan bahwa penggunaan serat bambu dan semen sangat berpengaruh pada nilai kuat lentur yang dihasilkan.

3. Kemampuan panel serat semen yang menggunakan campuran serat bambu dalam menyerap air dengan variasi campuran yang berbeda menunjukkan perbedaan yang kecil, berdasarkan gambar 6 dapat disimpulkan bahwa semakin banyak penggunaan serat bambu maka penyerapan air akan bertambah.Hal ini disebabkan dari sifat serat yang digunakan dapat menyerap air.

\section{Implikasi}

Dari hasil penelitian yang telah dilakukan didapatkan hasil kuat lentur panel serat semen yang menggunakan bahan campuran serat bambu ternyata tidak lebih tinggi dari kuat lentur yang ditetapkan SNI 15-0233-1989 mengenai "Mutu dan cara uji lembaran serat semen", secara umum panel serat semen dapat digunakan untuk dinding penyekat ruangan tetapi harus dilakukan penelitian ulang dengan syarat sebelum pembuatan benda uji semen harap diteliti terlebih dahulu untuk menghindari penggunaan semen palsu yang dapat menurunkan kualitas panel serat semen tersebut.

\section{Saran}

Berdasarkan pembahasan masalah dan kesimpulan diatas, dapat diajukan saran-saran sebagai berikut : 
1. Dilakukan penelitian lebih lanjut dengan cara membandingkan hasil kuat lentur panel serat semen dengan 2 cara perawatan yaitu di rendam air dan langsung di oven setelah pembuatan.

2. Sebelum pembuatan benda uji maka semen terlebih dahulu diteliti untuk menghindari penggunaan semen palsu yang sudah marak beredar.

3. Hendaknya pengadukan campuran dilakukan dengan menggunakan mesin pengaduk untuk mendapatkan campuran yang homogen.

\section{DAFTAR PUSTAKA}

Frick, Heinz. Ilmu Konstruksi Bangunan Bambu. (Yogyakarta : Kanisius, 2004),h.7.

Miko Erniarti, Ismail Hoesain. Kuat Lentur Plat Lantai Komposit Kayu-Beton Agregat Ringan Dengan Fibre Serat Bambu. (NTB : Laporan Penelitian Fakultas Teknik, Universitas Mataram, 2007),h.8.

SNI 15-0233-1989. Mutu dan Cara Uji Lembaran Serat Semen. Dewan Standarisasi Nasional.

SNI 15-0233-1989. Mutu dan Cara Uji Lembaran Serat Semen. Dewan Standarisasi Nasional. h, 1 .

SNI 15-7064-2004, Semen Komposit (Jakarta : Badan Standardidasi Nasional, 2004

Suparjo, Shofia Rawiana. Pemanfaatan Serat Bambu Untuk Dinding Beton Ringan Tanpa Pasir Pracetak Dengan Tulangan Bambu. (NTB : Laporan Penelitian Fakultas Teknik, Universitas Mataram, 2002),h.14. 